\title{
Evaluation of Genetic Parameters for Physiological and Biochemical Traits in Tomato (Solanum lycopersicum L.)
}

\author{
Manish Kumar ${ }^{1}$, R.K. Yadav ${ }^{1}$, Ajay Arora ${ }^{2}$, Manoj Kumar' ${ }^{1}$ and Akshay Talukdar ${ }^{3}$ \\ ${ }^{1}$ Division of Vegetable Science, ICAR-Indian Agricultural Research Institute, \\ New Delhi-110012, India \\ ${ }^{2}$ Division of Plant Physiology, ICAR-Indian Agricultural Research Institute, \\ New Delhi-110012, India \\ ${ }^{3}$ Division of Genetics and Plant Breeding, ICAR-Indian Agricultural Research Institute, \\ New Delhi-110012, India \\ *Corresponding author
}

\section{A B S T R A C T}

The present experiment aimed to evaluate variability, heritability and genetic advance as per cent over mean for physiological and biochemical traits in twenty one thermo tolerant

\section{Keywords}

Tomato, Variability, Heritability, Coefficient of variation, Genetic advance.

Article Info

Accepted:

20 February 2017

Available Online:

10 March 2017 tomato genotypes. The experiment was conducted at the Experimental Farm, Division of Vegetable Science, Indian Agricultural Research Institute, New Delhi during springsummer season (March-June) of the year 2014. Analysis of variance indicated highly significant mean sum of square due to treatment for all the traits and there was a sufficient amount of genetic variation in all the genotypes under study. Phenotypic coefficient of variation (PCV) was higher than the corresponding genotypic coefficient of variation (GCV) in most of the traits under the experiment. High PCV was observed in the characters viz., yield per plant (39.15), chlorophyll 'b' (24.40), chlorophyll 'a' (22.71), total chlorophyll (21.94) and lycopene content (22.46), whereas high GCV was recorded for yield per plant (38.79), chlorophyll ' $b$ ' (24.00), chlorophyll 'a' (22.26), total chlorophyll (20.95) and lycopene content (20.99). Yield per plant recorded maximum heritability $(98.84 \%)$ followed by TSS $(98 \%)$, proline $(95 \%)$ and membrane stability index (MSI) (95\%). High heritability coupled with high genetic advance was recorded in yield per plant, chlorophyll ' $b$ ', chlorophyll ' $a$ ' and total chlorophyll content. Similarly a joint consideration of heritability, GCV and genetic advance revealed high value for yield per plant, chlorophyll ' $b$ ', chlorophyll ' $a$ ' and total chlorophyll content. This showed that selection for these traits may be highly effective.

\section{Introduction}

Tomato (Solanum lycopersicum L.) is a selfpollinated, annual, herbaceous vegetable crop with $2 n=24$ chromosomes and belongs to the family Solanaceae. Firmly ripe tomato fruits can be used to prepare wide range of value added products, such as powder, sauce, ketchup, soup and whole canned fruits.
Unripe green fruits are used for the preparation of pickles and chutney. It also forms an ingredient for the cocktail Blood marry. In fact, tomato tops the list of processed vegetables and occupies a distinct place in the realm of vegetables because of its large-scale utilization and high nutritive value 
as it contains a good amount of vitamin A and $\mathrm{C}$ and minerals (Singh et al., 2004). Tomato is considered as an important source of ascorbic acid, $\beta$-carotene and lycopene, which are having antioxidant properties. Hence, its fruits are valued for their colour and flavour (Radzevicius et al., 2009). The phenotypic expression of the plant characters is mainly controlled by the genetic makeup of the plant and the environment in which it is growing. Further, the genetic variance of any quantitative trait is composed of additive variance (heritable) and non-additive variance and include dominance and epistasis (nonallelic interaction). Therefore, it becomes necessary to partition the observed phenotypic variability into its heritable and non-heritable components with suitable parameters such as genotypic and phenotypic coefficient of variation, heritability and genetic advance. Further, genetic advance can be used to predict the efficiency of selection. Therefore this study was conducted to estimate the genetic variation, heritability and genetic advance for various traits of tomato genotypes.

\section{Materials and Methods}

The present investigation was carried out at the Research Farm of Division of Vegetable Science, Indian Agricultural Research Institute, New Delhi (latitude 28 40' North, longitude $77^{\circ} 12^{\prime}$ East and at an altitude of $228.6 \mathrm{~m}$ above mean sea level) during the summer season (March-June) of the year 2014. The climate of Delhi is semi-arid with hot summers and cool winters. The weather data of the season during this investigation is presented in table 1 . The study material comprised of twenty one diverse thermo tolerant genotypes of tomato (Table 2). The experiment was laid out in randomized block design with 3 replications. The recommended cultural practices were followed to raise a healthy crop. Various physiological and biochemical parameters viz., relative water content (as described by Brass and Weatherley, 1962), membrane stability index (as described by Premachandra et al., 1990), chlorophyll content (a, b and total chlorophyll, chlorophyll a/b ratio) (as described by Hiscox and Israelstam, 1979), TSS and lycopene content (as described by Ranganna, 1977), ascorbic acid and acidity (as described in A.O.A.C., 1975) and proline content (as described by Bates et al., 1973) were estimated by maximum likelyhood. The mean data were used for statistical analysis to estimate genetic variability, phenotypic and genotypic coefficient of variation (Burton and De-Vane, 1953), heritability (Falconer, 1981) and genetic advance (Johnson, 1955).

\section{Results and Discussion}

The combined mean performance of different tomato genotypes for various physiological and biochemical traits is presented in table 3 . Relative water content (RWC) and membrane stability index (MSI) had high value under stress condition in tolerant genotypes. All the genotypes recorded decreasing trend of relative water content and membrane stability index under heat stress condition. However, the per cent decrease in RWC and MSI was low in tolerant genotypes compared to heat sensitive genotypes. Heat tolerant genotypes, like Pusa Sadabahar recorded maximum value of RWC and MSI $(83 \%$ and $86 \%$ respectively) followed by $\mathrm{Spr}-1$ and $\mathrm{Spm}$ (82\% and $82.7 \% ; 80 \%$ and $85 \%$ respectively). In contrast to these, heat sensitive genotypes, like Pusa Ruby, Pusa 120, Pusa Rohini and Pusa Gaurav recorded low value of RWC and MSI $(66 \%$ and 63\%; 65\% and $70.67 \%$; $64.41 \%$ and $71 \% ; 69 \%$ and $66 \%$ respectively). These results were in close confirmation with the findings of Hayat et al., (2008). This showed that RWC and MSI may be used as rapid and reliable method to identify heat tolerant genotypes. 
Chlorophyll content of leaves, which is a vital component of photosynthetic activity in plant, was influenced significantly under heat stress condition. Reduction in chlorophyll content (a, b and total chlorophyll) was recorded under heat stress. Very high reduction in chlorophyll ' $a$ ' and ' $b$ ' was recorded in heat sensitive genotype, like Pusa Rohini (58\% and $50 \%$ respectively) as compared to heat tolerant genotype Pusa Sadabahar (11.5\% and $28 \%$ respectively). Tolerant genotypes showed high value of chlorophyll ' $b$ ' under heat stress condition as compared to sensitive genotypes. High chlorophyll $\mathrm{a} / \mathrm{b}$ ratio was recorded in sensitive genotypes, like Pusa Ruby, Pusa 120, Pusa Gaurav (4.39, 4.17 and 4.46 respectively), while tolerant genotypes, namely Pusa Sadabahar, LP2 and TH-348-T2 recorded low value of $\mathrm{a} / \mathrm{b}$ ratio $(3.87,2.47$ and 3.32 respectively). This showed that low value of $\mathrm{a} / \mathrm{b}$ ratio gives better tolerance under heat stress condition. Similar results were also reported by Somkuwar et al., (2015). There was no clear cut trend for TSS and acidity. However slightly higher level of TSS and acidity was recorded in tolerant genotypes under heat stress.

Table.1 Standard meteorological month's average weather data during the experiment

\begin{tabular}{|c|c|c|c|c|}
\hline & March & April & May & June \\
\hline Maximum Temperature $\left({ }^{\circ} \mathrm{C}\right)$ & 26.86 & 34.77 & 38.70 & 41.71 \\
\hline Minimum Temperature $\left({ }^{\circ} \mathrm{C}\right)$ & 12.73 & 18.02 & 22.58 & 26.55 \\
\hline Average Temperature $\left({ }^{\circ} \mathrm{C}\right)$ & 19.79 & 26.34 & 30.64 & 34.13 \\
\hline Relative Humidity (Morning) $(\%)$ & 90.03 & 73.43 & 73.74 & 69.57 \\
\hline Relative Humidity (Evening) (\%) & 48.06 & 40.13 & 42.97 & 36.60 \\
\hline Average Relative Humidity (\%) & 69.05 & 56.78 & 58.35 & 53.08 \\
\hline Rainfall (mm) & 63.50 & 16.40 & 79.60 & 59.60 \\
\hline Sunshine (hours) & 6.37 & 8.44 & 8.09 & 7.26 \\
\hline Evaporation $(\mathrm{mm})$ & 3.71 & 6.76 & 8.20 & 10.92 \\
\hline Average wind speed $(\mathrm{Km} / \mathrm{h})$ & 4.92 & 6.06 & 6.66 & 8.04 \\
\hline
\end{tabular}

Table.2 Various tomato varieties and genotypes used as experimental material in the study

\begin{tabular}{|c|l|l|c|l|l|}
\hline Sl. No. & \multicolumn{2}{|c|}{ Varieties/genotypes } & Sl. No. & \multicolumn{2}{c|}{ Varieties/genotypes } \\
\hline 1. & Pusa Sadabahar & HT & 12. & TH-348-4-R & HT \\
\hline 2. & Pusa Ruby & HS & 13. & TH-348-4-2 & HT \\
\hline 3. & Pusa 120 & HS & 14. & TH-348-4-5-1 & HT \\
\hline 4. & Pusa Rohini & HS & 15. & Spr-1* & HT \\
\hline 5. & Pusa Gaurav & HS & 16. & Spr-2* & HT \\
\hline 6. & Pusa Sheetal & HT & 17. & Spm** & HT \\
\hline 7. & Chikko & HT & 18. & SPM * $^{*}$ & HT \\
\hline 8. & LP-2 & HT & 19. & SPM 2** & HT \\
\hline 9. & PSH-3 & HT & 20. & SPM 3** & HT \\
\hline 10. & TH-348-T2 & HT & 21. & SPM 4** & HT \\
\hline 11. & Balkan & HT & & & \\
\hline
\end{tabular}

(Where HT-heat tolerant, HS-heat sensitive and $*$ S. peruvianum, $* *$ S. pimpinellifolium) 
Table.3 Mean performance of various tomato genotypes for physiological and biochemical traits under heat stress

\begin{tabular}{|c|c|c|c|c|c|c|c|c|c|c|c|c|c|}
\hline $\begin{array}{l}\text { Sl. } \\
\text { No. }\end{array}$ & Genotypes & $\begin{array}{c}\text { RWC } \\
(\%)\end{array}$ & MSI (\%) & $\begin{array}{c}\text { Chl a } \\
(\mathrm{mg} / \mathrm{g})\end{array}$ & $\begin{array}{c}\text { Chl b } \\
(\mathrm{mg} / \mathrm{g})\end{array}$ & $\begin{array}{c}\text { Total chl } \\
\text { (mg/g) }\end{array}$ & $\begin{array}{c}\text { Chl a/b } \\
\text { ratio }\end{array}$ & $\begin{array}{c}\text { TSS } \\
\left({ }^{\circ} \text { Brix }\right)\end{array}$ & $\begin{array}{l}\text { Lycopene } \\
(\mathrm{mg} / \mathbf{1 0 0 g})\end{array}$ & $\begin{array}{c}\text { Ascorbic } \\
\text { Acid } \\
(\mathbf{m g} / \mathbf{1 0 0 g})\end{array}$ & $\begin{array}{c}\text { Acidity } \\
(\%)\end{array}$ & $\begin{array}{c}\text { Proline } \\
(\mu \mathrm{g} / \mathrm{g})\end{array}$ & $\begin{array}{c}\text { Yield } \\
\text { /plant } \\
\text { (g) }\end{array}$ \\
\hline 1 & Pusa Sadabahar & 83.36 & 86.00 & 1.50 & 0.40 & 1.90 & 3.87 & 5.33 & 2.35 & 13.37 & 0.42 & 347.33 & 685 \\
\hline 2 & Pusa Ruby & 66.67 & 63.70 & 1.38 & 0.31 & 1.69 & 4.39 & 5.03 & 1.10 & 17.93 & 0.35 & 266.33 & 290 \\
\hline 3 & Pusa 120 & 65.06 & 70.67 & 1.04 & 0.22 & 1.22 & 4.17 & 5.20 & 1.24 & 17.33 & 0.33 & 280.42 & 280 \\
\hline 4 & Pusa Rohini & 64.41 & 71.00 & 0.78 & 0.20 & 0.99 & 3.80 & 5.23 & 1.04 & 18.50 & 0.32 & 284.67 & 285 \\
\hline 5 & Pusa Gaurav & 69.39 & 66.67 & 0.97 & 0.22 & 1.16 & 4.46 & 5.40 & 1.04 & 15.17 & 0.34 & 272.67 & 342 \\
\hline 6 & Pusa Sheetal & 74.40 & 79.67 & 1.52 & 0.40 & 1.94 & 3.58 & 5.20 & 1.86 & 18.27 & 0.38 & 319.67 & 557 \\
\hline 7 & Chikko & 73.64 & 79.67 & 1.21 & 0.25 & 1.36 & 3.93 & 5.63 & 1.52 & 18.50 & 0.39 & 371.67 & 514 \\
\hline 8 & LP-2 & 75.07 & 82.33 & 0.94 & 0.38 & 1.32 & 2.47 & 6.37 & 2.09 & 15.73 & 0.36 & 356.53 & 610 \\
\hline 9 & PSH-3 & 78.17 & 76.00 & 0.69 & 0.19 & 0.96 & 3.84 & 5.77 & 1.88 & 15.20 & 0.44 & 357.01 & 548 \\
\hline 10 & TH-348-T2 & 75.82 & 80.67 & 1.43 & 0.43 & 1.81 & 3.32 & 5.90 & 1.59 & 13.90 & 0.34 & 395.33 & 542 \\
\hline 11 & Balkan & 77.67 & 78.33 & 1.36 & 0.36 & 1.68 & 4.04 & 6.27 & 1.93 & 12.60 & 0.35 & 339.31 & 605 \\
\hline 12 & TH-348-4-R & 76.42 & 81.67 & 1.36 & 0.34 & 1.72 & 3.84 & 5.37 & 1.71 & 18.33 & 0.37 & 354.01 & 594 \\
\hline 13 & TH-348-4-2 & 73.67 & 81.86 & 1.36 & 0.38 & 1.74 & 3.60 & 5.60 & 1.56 & 19.23 & 0.33 & 386.42 & 582 \\
\hline 14 & TH-348-4-5-1 & 79.14 & 83.33 & 1.09 & 0.40 & 1.51 & 2.58 & 6.30 & 1.83 & 23.13 & 0.35 & 394.17 & 568 \\
\hline 15 & Spr-1 & 82.67 & 82.67 & 1.54 & 0.44 & 1.98 & 3.51 & 7.00 & 1.85 & 21.27 & 0.30 & 398.32 & 152 \\
\hline 16 & Spr-2 & 77.33 & 85.00 & 1.90 & 0.36 & 2.27 & 5.25 & 7.67 & 2.08 & 22.17 & 0.40 & 385.67 & 160 \\
\hline 17 & Spm & 80.87 & 85.67 & 1.36 & 0.39 & 1.72 & 3.79 & 8.07 & 2.13 & 24.37 & 0.45 & 417.33 & 170 \\
\hline 18 & SPM1 & 79.33 & 78.00 & 1.38 & 0.31 & 1.65 & 4.16 & 7.87 & 2.10 & 20.83 & 0.40 & 345.33 & 183 \\
\hline 19 & SPM2 & 76.03 & 79.67 & 1.31 & 0.44 & 1.66 & 2.94 & 7.70 & 1.97 & 20.47 & 0.34 & 352.67 & 180 \\
\hline 20 & SPM3 & 74.75 & 75.00 & 1.16 & 0.32 & 1.49 & 3.80 & 8.10 & 1.86 & 20.30 & 0.32 & 381.67 & 188 \\
\hline \multirow[t]{5}{*}{21} & SPM4 & 72.66 & 76.67 & 1.59 & 0.41 & 2.00 & 3.90 & 8.27 & 1.88 & 21.07 & 0.37 & 381.39 & 190 \\
\hline & Mean & 75.07 & 78.30 & 1.28 & 0.34 & 1.61 & 3.77 & 6.35 & 1.74 & 18.46 & 0.36 & 351.81 & 391.60 \\
\hline & SED & 1.50 & 1.07 & 0.05 & 0.01 & 0.09 & 0.24 & 0.13 & 0.11 & 0.98 & 0.03 & 7.48 & 4.79 \\
\hline & $\mathrm{CD}$ at $5 \%$ & 3.06 & 2.19 & 0.10 & 0.02 & 0.18 & 1.59 & 0.27 & 0.23 & 2.01 & 0.07 & 15.29 & 7.33 \\
\hline & $\mathrm{CV}$ & 2.44 & 1.67 & 6.81 & 9.90 & 6.52 & 9.32 & 2.53 & 7.99 & 6.53 & 11.40 & 2.60 & 0.70 \\
\hline
\end{tabular}


Table.4 Mean, range, PCV, GCV, heritability $\left(\mathrm{h}^{2}\right)$, genetic advance (GA) and genetic advance as per cent over mean of physiological and biochemical traits of 21 genotypes of tomato under heat stress

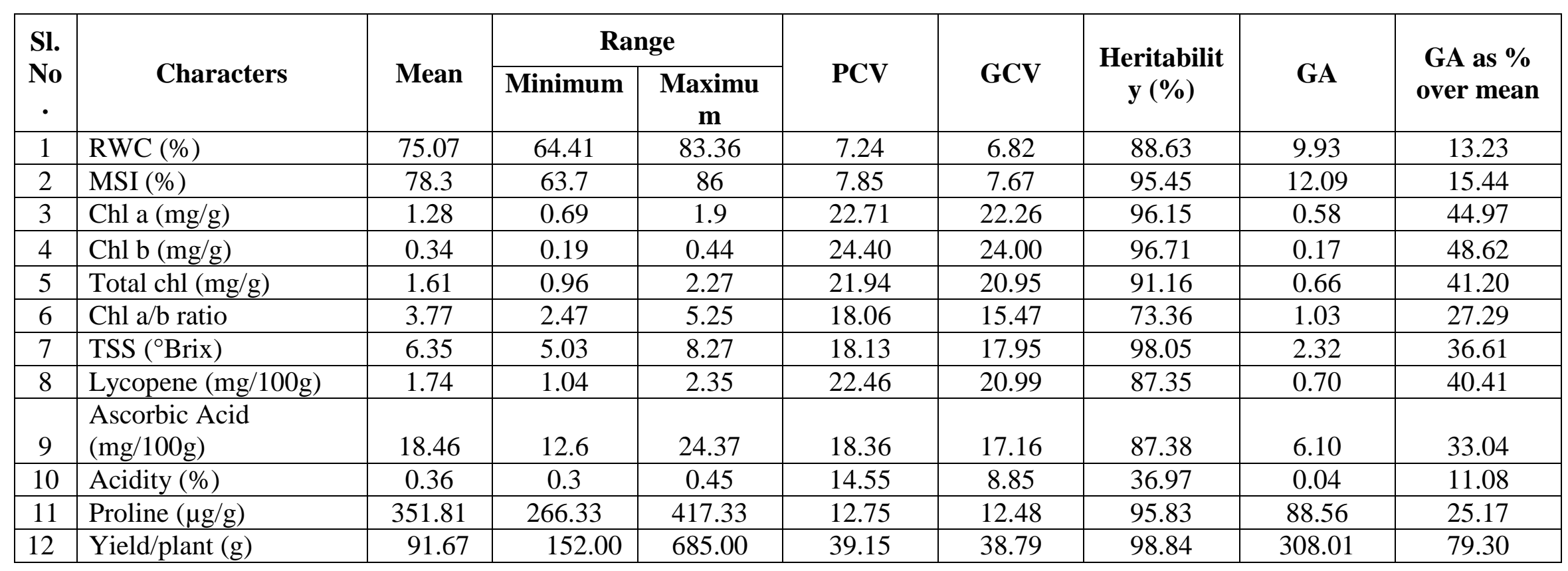


Ascorbic acid content was found maximum in genotype Spm $(24.37 \mathrm{mg} / 100 \mathrm{~g})$ and minimum in genotype Pusa Gaurav (15.17mg/100g) under stress condition. However, there was slight higher level of ascorbic acid content in heat tolerant genotypes as compared to heat sensitive genotypes. It was evident that lycopene content reduced significantly under heat stress condition in all the genotypes under study (Table 3). However the tolerant genotype Pusa Sadabahar showed less reduction (55\%) as compared to sensitive genotype Pusa Rohini (75\%). Proline content was significantly influenced with increase in temperature under this study. Highest proline content was recorded in wild genotypes like Spm $(417 \mu \mathrm{g} / \mathrm{g})$ followed by Spr-1 $(398 \mu \mathrm{g} / \mathrm{g})$ and TH-348-4-5-1 (394 $\mu \mathrm{g} / \mathrm{g})$.

Phenotypic coefficient of variation (PCV) value was higher than the corresponding genotypic coefficient of variation (GCV) value in almost all the traits under this study (Table 4). High value of PCV and GCV was recorded in yield per plant (39.15 and 38.79), chlorophyll 'a' (22.71 and 22.30), chlorophyll 'b' (24.40 and 24.00), total chlorophyll (21 and 20) and lycopene content (22 and 20). Wide difference in PCV and GCV was recorded in acidity.

Heritability $\left(\mathrm{h}^{2}\right)$ in broad sense was found high in most of the traits. Yield per plant recorded maximum heritability (98.84\%) followed by TSS (98\%), proline (95\%), MSI (95\%) and ascorbic acid (87\%). This result was in accordance with the findings of Kumar and Tewari (1999) and Dar and Sharma (2011) in tomato. Acidity recorded low heritability (36\%). Similarly genetic advance as per cent over mean was recorded maximum for yield per plant (79.30) followed by chlorophyll ' $b$ ' (48.62), chlorophyll ' $a$ ' (44.97) and total chlorophyll content (41.20). High heritability coupled with high genetic advance was recorded in yield per plant, chlorophyll 'b', chlorophyll 'a' and total chlorophyll content. High heritability and genetic advance for TSS, which was similar to our finding was also reported by Singh et al., (2000), Joshi and Singh (2003), Mehta and Asati (2008) and Shashikant et al., (2010). Similarly a joint consideration of heritability, GCV and genetic advance revealed high value for yield per plant, chlorophyll 'b', chlorophyll ' $a$ ' and total chlorophyll content.

Thus, results from the present investigation clearly explained that there was a greater variation for all the characters in the genotypes under the study. Phenotypic coefficient of variation was higher than the corresponding genotypic coefficient of variation in all the traits. High PCV was observed for yield per plant followed by chlorophyll 'b', chlorophyll 'a', total chlorophyll and lycopene content. When heritability, GCV and genetic advance considered jointly, indicated high value for yield per plant, chlorophyll ' $b$ ', chlorophyll ' $a$ ' and total chlorophyll content. This showed that selection for these traits may be highly effective in crop improvement programme.

\section{Acknowledgement}

The author is thankful to Indian Agricultural Research Institute, New Delhi for providing the experimental material as well as lab and other facilities during the research work.

\section{References}

A.O.A.C. 1975. In: Official Methods of Analysis. Publication of the Association of Analytical Chemists. Washington DC, USA. Pp. 401-404 and 829-831.

Bates, L.S., Waldren, R.P., Teare, I.D. 1973. Rapid determination of free proline for water stress studies. Plant and Soil, 39: 205-207. 
Brass, H.D., Weatherley, P.E. 1962. A reexamination of the relative turgidity technique for estimating water deficits in leaves. Aus. J. Bio. Sci., 15: 143-28.

Burton, G.W., De-Vane, E.H. 1953. Estimating heritability in tall fescue (Festuca arundinancea) from replicated clonal materials. Agro. J., 45: 478-481.

Dar, R.A., Sharma, J.P. 2011. Genetic variability studies of yield and quality traits in tomato (Solanum lycopersicum L.). Int. J. Plant Breed. Genet., 5(2): 168-174.

Hayat, S., Hasan, S.A., Fariduddin, Q., Ahmad, A. 2008. Growth of tomato (Lycopersicon esculentum) in response to salicylic acid under water stress. $J$. Plant Int., 3(4): 297-304.

Hiscox, J.D., Israelstam, G.F. 1979. A method for extraction of chlorophyll from leaf tissue without maceration. Can. J. Bot., 57: 1332-1334.

Johnson, H.W., Robinson, H.F., Comstock, R.E. 1955. Estimates of genetic and environmental variability in soya bean. Agro. J., 47: 314-318.

Joshi, A., Singh, J.P. 2003. Studies on genetic variability in tomato. Prog. Hort., 35(2): 179-182.

Kumar, T.P., Tewari, R.N. 1999. Studies on genetic variability for processing characters in tomato. Indian J. Hort., 56(4): 332-336.

Mehta, N., Asati, B.S. 2008. Genetic relationship of growth and developmental traits with fruit yield in tomato (Lycopersicon esculentum Mill.). Karnataka J. Agri. Sci., 21(1): 92-96.

Premachandra, G.S., Saneoka, H., Ogata, S. 1990. Cell membrane stability an indicator of drought tolerance as affected by applied $\mathrm{N}$ in soybean. $J$. Agri. Sci., 115: 63-66.

Radzevicius, A., Karkleliene, R., Bobinas, C., Viskelis, P. 2009. Nutrition quality of different tomato cultivars. ZemdirbysteAgri., 96(3): 67-75.

Ranganna, S. 1977. In: Manual for Analysis of Fruit and Vegetable Products. Tata McGraw Hill Publ. Co. Ltd., New Delhi. Pp. 634.

Shashikant., Basavaraj, N., Hosamani, R.M., Patil, B.C. 2010. Genetic variability in tomato [Solanum lycopercsicon (Mill.)Wettsd.]. Karnataka J. Agri. Sci., 23(3): 536-537.

Singh, J.P., Singh, D.K., Lal, G. 2000. Variability pattern in Agro morphological characters in tomato (Lycopersicun esculentum Mill.). Prog. Hort., 32(1): 79-81.

Somkuwar, R.G., Taware, P.B., Bhange, M.A., Sharma, J., Khan, I. 2015. Influence of Different Rootstocks on Growth, Photosynthesis, Biochemical Composition and Nutrient Contents in 'Fantasy Seedless' Grapes. Int. J. Fruit Sci., 15(3): 251-266.

\section{How to cite this article:}

Manish Kumar, R.K. Yadav, Ajay Arora, Manoj Kumar and Akshay Talukdar. 2017. Evaluation of Genetic Parameters for Physiological and Biochemical Traits in Tomato (Solanum lycopersicum L.). Int.J.Curr.Microbiol.App.Sci. 6(3): 1332-1338. doi: https://doi.org/10.20546/ijcmas.2017.603.154 